\title{
ARTICLE
}

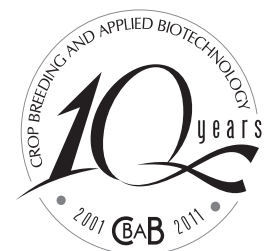

\section{Seasonal and genetic influences on sex expression in a backcrossed segregating papaya population}

\author{
Helaine Christine Cancela Ramos ${ }^{1}$, Messias Gonzaga Pereira ${ }^{1}{ }^{*}$, Francisco Filho da Silva ${ }^{2}$, Alexandre Pio Viana ${ }^{1}$ and Geraldo Antônio \\ Ferreguetti ${ }^{3}$
}

Received 22 January 2010

Accepted 5 October 2010

\begin{abstract}
This study aimed to evaluate the genetic and seasonal influence on sex expression in segregating generations of papaya elite and backcrossed genotypes. In the four seasons of the 2005/2006 growing season, 200 hermaphrodite plants were evaluated. Of the eight studied traits, four were related to flowering and four to fruiting, i.e., to the percentage of normal, deformed, sterile, and total number of flowers, as well as the percentage of total, carpelloid, pentandric, and marketable fruits. Significant differences due to the genotype $x$ season interaction were verified. Based on the genotypic determination coefficient and the variation index it was concluded that winter and spring are most appropriate for the selection of superior genotypes. Thus, selection in early stages of plant development is more successful, indicating that the physiological age may also be a factor involved in the expression of the above traits.
\end{abstract}

Key words: Carica papaya L.; flower malformation; sex reversal; seasonality.

\section{INTRODUCTION}

The commercial papaya (Carica papaya L.) is a trioecious species with three morphologically distinct sexual forms: female, male and hermaphrodite. In Brazil, as in other tropical countries, the gynoecious-andromonoecious varieties are preferred, i.e., those consisting of female and hermaphrodite plants that produce marketable fruit for fresh consumption. These populations are derived from crosses between hermaphrodite plants, in other words, selfing, resulting in a 2:1 segregation of female and hermaphrodite plants. This is somewhat advantageous for producers, since only the hermaphrodite plants remain in the plantations after the definitive sexing procedure, once consumers prefer fruits of hermaphrodite plants (Storey 1953, Khan et al. 2002).

Recent molecular studies have shown that sex determination in this species is controlled by a recently evolved homomorphic pair of sex chromosomes (type $\mathrm{X} /$ $\mathrm{Y})$, differentiated by a small male-specific region on the $\mathrm{Y}$ chromosome (MSY). In this sense, the female plants are homogametic with the XX chromosomes, whereas male and hermaphrodite plants are heterogametic, with XY and $\mathrm{XY}^{\mathrm{h}}$ chromosome combinations, respectively (Liu et al. 2004). It is likely that two genes are involved in papaya sex determination, one a suppressor of the stamen in female flowers (feminizing gene) and the other gene a suppressor of carpel in male flowers (masculinizing gene) (Ming et al.

\footnotetext{
${ }^{1}$ Universidade Estadual do Norte Fluminense Darcy Ribeiro, Laboratório de Melhoramento Genético Vegetal, 28.013-600, Campos dos Goytacazes, RJ, Brazil. *Email: messias@uenf.br

${ }^{2}$ Instituto Federal de Educação, Ciência e Tecnologia do Tocantins, Campus Araguatins, 77950-000, Araguatins, TO, Brazil

${ }^{3}$ Caliman Agrícola S.A., 29.900-970, Linhares, ES, Brazil
} 
2007). More recent research has detected seven genes in the sex-controlling region, which were however not able to differentiate the three sex types, because there was neither differential expression nor dosage effect, suggesting that these genes are not involved in sex determination ( $\mathrm{Yu}$ et al. 2008).

Despite certain progress in research on the molecular mechanisms of papaya sex determination, there is little understanding of the expression of the sexual forms and variations, which are directly related to the production efficiency of marketable fruit. This issue is considered complex and intriguing in view of the lethal factor associated with the dominant alleles responsible for hermaphroditism and masculinity (Storey 1953, Ming et al. 2007), aside from the influence of genetic and environmental factors on both (Awada 1958, Arkle Junior and Nakasone 1984, Silva et al. 2007a, Damasceno Júnior et al. 2008). The combination of these factors is possibly responsible for the high degree of instability of hermaphrodite plants in terms of sex expression; a variation of flowers to carpelloid and pentandric forms or sex reversal are possible. These variations of the hermaphrodite flower, classified as floral abnormalities, reduce crop yields and increase seasonality in fruit yield, leading to supply oscillations and consequently to price variations of papaya on the market.

Carpelloid fruits occur due to the transformation of stamens into carpel-like structures, producing fruit with varying degrees of malformation, while pentandry is the transformation of hermaphrodite into a typically female flower, with a reduced number of stamens and an ovary with five deep grooves. These variations occur mainly at mild or low temperatures and high moisture and soil nitrogen levels (Awada 1958, Arkle Junior and Nakasone 1984) and are undesirable in plantations, since their fruit has no marketable value, decreasing yields. Sex reversal on the other hand is a result of abortion or ovarian atrophy, producing no fruit. This phenomenon occurs related to high temperatures, water stress and low soil nitrogen (Awada 1958, Arkle Junior and Nakasone 1984).

In this sense, the purpose of this study was to quantify seasonal and genetic influences on sex expression in papaya, to identify the best seasons for selection with a view to minimize floral disturbances in future improved cultivars. Information was compiled in four seasons on the occurrence of flower and fruit malformation and sex reversal in hermaphrodite flowers of segregating generations derived from backcrosses and elite genotypes.

\section{MATERIAL AND METHODS}

\section{Plant material}

Backcrossed hermaphrodite plants of the segregating treatments $16 \mathrm{BC}_{1} \mathrm{~S}_{1}, 52 \mathrm{BC}_{1} \mathrm{~S}_{1}, 115 \mathrm{BC}_{1} \mathrm{~S}_{1}, \mathrm{BC}_{2}$, and $\mathrm{BC}_{1} \mathrm{X}$ 'SS72/12' were evaluated, of which the recurrent parent was genotype Cariflora and the donor parent of hermaphroditism the elite variety Sunrise Solo 783. Besides, 15 plants each of the cultivars 'Golden' and Sunrise Solo 783 (both 'Solo' elite varieties) were evaluated for comparison.

The first three genotypes cited had been obtained by selfing of the plants 16,52 and 115 , which had been backcrossed with genotype Cariflora $\left(\mathrm{BC}_{1}\right)$ and the segregating generation $\mathrm{BC}_{2}$ was obtained by a second backcross with genotype Cariflora $\left(\mathrm{BC}_{2}\right)$. On the other hand, 'SS72/12' $\mathrm{X} \mathrm{BC}_{1}$ was derived from a cross between a superior segregating $\mathrm{BC}_{1}$ plant and a plant of the elite variety 'Sunrise Solo 72/12'.

This backcross population was established with a view to convert the dioecious sex of parent Cariflora to gynoecious-andromonoecious (Silva et al. 2007b).

\section{Experimental site and conduction}

The experiment was conducted in a plantation of the company Caliman Agrícola S/A (Fazenda Romana) in Linhares, State of Espírito Santo. The regional climate is Awi (tropical humid, Köppen), rainy in the summer and dry in the winter. The terrain is flat, forming a so-called coastal plateau, at 28 to $65 \mathrm{~m}$ asl (Rolim et al. 1999).

The evaluations were initiated on January 25, 2005, in a randomized block design with seven treatments and two replications. The seedlings were transplanted to two rows spaced $3.6 \mathrm{~m}$ apart, with a final plant spacing of 1.5 $\mathrm{m}$. The plots consisted of $36,33,17,24,60,15$, and 15 plants in the treatments $16 \mathrm{BC}_{1} \mathrm{~S}_{1}, 52 \mathrm{BC}_{1} \mathrm{~S}_{1}, 115 \mathrm{BC}_{1} \mathrm{~S}_{1}$, ' $\mathrm{SS}$ $72 / 12$ ' x BC $1, \mathrm{BC}_{2}$, SS 783, and 'Golden', respectively. The variation in the number of plants per plot was related to the availability of seedlings as well as sexing procedures, coupled with plant loss due to the occurrence of virus during the experiment. Due to the high degree of segregation expected, the $\mathrm{BC}_{2}$ treatment consisted of 60 plants in each replication to ensure enough plants for selection to obtain the $\mathrm{BC}_{3}$ generation.

Fertilization, management, pest and disease control and cultural practices were applied as usual in the plantations of the company. 


\section{Traits evaluated}

The evaluation consisted of counting the total number of hermaphrodite flowers (TNHF), deformed hermaphrodite (NDHF), sterile hermaphrodite (NSHF) and normal hermaphrodite flowers (NNHF), represented by elongate flowers. The NDHF includes all carpelloid and pentandric flowers, in view of the difficulty of differentiation by the external phenotype. The total number of hermaphroditic flowers (TNHF) is the sum of NDHF, NSHF and NNHF. Besides the flower, fruit traits were evaluated: total number of fruits (TNFr), number of carpelloid (NCFr), pentandric (NPFr) and of marketable fruits (NMFr). On average, 200 hermaphrodite plants were evaluated at the end of each season for the above traits.

\section{Environmental conditions}

Climate data of the municipality of Linhares-ES were obtained at the CECAM (Center of Meteorology and Water Management of Espírito Santo) unit INCAPER (Research Institute of Espírito Santo). The regional mean weather data were recorded (INCAPER 2006) in winter, spring, summer and autumn, (temperatures $21.8^{\circ} \mathrm{C}, 24.6^{\circ} \mathrm{C}, 26.5^{\circ} \mathrm{C}$, and $22.6^{\circ} \mathrm{C}$; rain $48.5,162.2,150.2$, and $28.6 \mathrm{~mm}$; relative humidity $80,83.3,83$, and $84.7 \%$, respectively).

\section{Statistical analysis}

Analyses of variance related to flowering and fruiting, according to the experimental design I (fixed model) were performed using SAS (SAS Institute 1992), based on the split-plot-in-time model, as described by Steel and Torrie (1980) (Table 1).

Based on the combined and season-specific analysis of variance, estimates of variance components were obtained for the mean square expectation (Table 1). From these estimates the genetic parameters were calculated for each trait, based on the methodology proposed by Fehr (1987), as shown below:

a) coefficient of genotypic determination

$$
H^{2}=\frac{M S_{2}-M S_{3}}{M S_{2}}
$$

b) Coefficient of genetic variation $C V_{g(\%)}=\frac{100 \times \sqrt{\phi_{G}}}{\bar{X}}$, were $\phi_{G}=\frac{M S_{2}-M S_{3}}{r n e}$

c) Coefficient of experimental variation $C V_{e(\%)}=\frac{100 \times \sqrt{\sigma_{e}^{2}}}{\bar{X}}$, were $\sigma_{e}^{2}=\frac{M S_{6}}{n}$

d) Index of variation $I_{v}=\frac{C V_{g}}{C V_{e}}$.

\section{RESULTS AND DISCUSSION}

The analysis of variance (Table 2) indicated significant differences between genotypes using the F test at $1 \%$ probability for almost all traits, indicating the availability of genetic variability among treatments and segregating elite cultivars. An exception to this result was observed for normal carpelloid fruits and flowers, indicating limited genetic divergence between treatments in the expression of these two traits. Similar results were found for the genotype $\mathrm{x}$ season interaction, suggesting a differentiated performance of the genotypes when exposed to seasonal environmental changes.

The season-specific variance analysis (Table 3) showed significant differences among genotypes for almost all traits by the F test at $5 \%$ probability in the four seasons, except for NNHF and NCFr in the summer and TNFr, NCFr, NMFr, and NNHF in the fall.

The estimates of the experimental coefficient of variation $\left(\mathrm{CV}_{\mathrm{e}}\right)$ (Table 3$)$ in the fall were higher for almost all traits, suggesting great variation among the families and indicating lower accuracy in the evaluation of the progenies in this season. In contrast, $\mathrm{CV}_{\mathrm{e}}$ estimates were lowest in the summer, indicating a lower error and higher experimental accuracy for an effective evaluation of the studied traits. The genotypic coefficient of variation $\left(\mathrm{CV}_{\mathrm{g}}\right)$ was highest in the winter and spring for most traits, indicating these as the most appropriate seasons for the identification and selection of superior segregating genotypes. In general, $\mathrm{CV}_{\mathrm{g}}$ values were lower in summer and autumn; particularly in the summer, the experimental variation coefficients $\left(\mathrm{CV}_{\mathrm{e}}\right)$ as well as genetic variation coefficients $\left(\mathrm{CV}_{\mathrm{g}}\right)$ were low.

The genetic variability of the genotypic determination coefficient $\left(\mathrm{H}^{2}\right)$ in the different seasons was high for all traits in the winter and spring, which was confirmed by high values of the index of variation $\left(\mathrm{I}_{\mathrm{v}}\right)$ and $\mathrm{CV}_{\mathrm{g}}$. On the other hand, in the summer evaluations there was a slight $\mathrm{H}^{2}$ increase in some traits (TNFr, NMFr, TNHF and NDHF), and $\mathrm{H}^{2}$ reduction for others (NPFr, NSHF, NCFr and NNHF) when compared to spring. Lowest $\mathrm{H}^{2}$ values were found in the fall, indicating a strong environmental influence on the trait expression, apart from the occurrence of adverse 
HCC Ramos et al.

Table 1. Analysis of variance for the evaluated morphoagronomical traits, with the respective mean square expectations, mean squares, considering the genotype and seasonal effects as fixed

\begin{tabular}{|c|c|c|c|c|}
\hline Source of variation & df & MS & MSE & $\mathbf{F}$ \\
\hline Block (B) & $\mathrm{r}-1$ & $\mathrm{MS}_{1}$ & $\sigma_{\mathrm{w}}^{2}+n \sigma^{2}+n e \sigma^{2} \mathrm{a}+n \mathrm{neg} \sigma_{\mathrm{B}}^{2}$ & $\mathrm{MS}_{1} / \mathrm{MS}_{3}$ \\
\hline Genotype (G) & g-1 & $\mathrm{MS}_{2}$ & $\sigma_{\mathrm{w}}^{2}+n \sigma^{2}+n e \sigma^{2} \mathrm{a}+\operatorname{ner} \phi_{\mathrm{G}}$ & $\mathrm{MS}_{2} / \mathrm{MS}_{3}$ \\
\hline Residue a $(\mathrm{G} \times \mathrm{B})$ & $(\mathrm{r}-1)(\mathrm{g}-1)$ & $\mathrm{MS}_{3}$ & $\sigma_{\mathrm{w}}^{2}+n \sigma^{2}+n e \sigma^{2} \mathrm{a}$ & - \\
\hline Season (S) & $\mathrm{s}-1$ & $\mathrm{MS}_{4}$ & $\sigma_{\mathrm{w}}^{2}+n \sigma^{2}+\operatorname{nrg} \phi_{\mathrm{S}}$ & $\mathrm{MS}_{4} / \mathrm{MS}_{6}$ \\
\hline$S \times G$ & $(\mathrm{~s}-1)(\mathrm{g}-1)$ & $\mathrm{MS}_{5}$ & $\sigma_{\mathrm{w}}^{2}+n \sigma^{2}+\mathrm{nr} \phi_{\mathrm{SG}}$ & $\mathrm{MS}_{5} / \mathrm{MS}_{6}$ \\
\hline Residue b (S x G x R) & $(\mathrm{s}-1)(\mathrm{g}-1)(\mathrm{r}-1)$ & $\mathrm{MS}_{6}$ & $\sigma_{\mathrm{w}}^{2}+n \sigma^{2}$ & - \\
\hline Plant/Genotype & $\operatorname{rgs}(n-1)$ & $\mathrm{MS}_{7}$ & $\sigma_{\mathrm{w}}^{2}$ & \\
\hline
\end{tabular}

Table 2. Combined analysis of variance of morphoagronomical papaya traits in segregating generations and elite genotypes

\begin{tabular}{|c|c|c|c|c|c|c|c|c|}
\hline \multicolumn{9}{|c|}{ Traits } \\
\hline & TNFr & NCFr & NPFr & NMFr & TNHF & NDHF & NSHF & NNHF \\
\hline GMS & $6,351.71 * *$ & 26.78 & $264.75^{* *}$ & $8,654.84 * *$ & $6,035.98 * *$ & $427.23 * *$ & $3,935.92 * *$ & 306.11 \\
\hline GSMS & $1,350.09 * *$ & 6.14 & $73.15^{* *}$ & $1,079.61^{* *}$ & $832.34 * *$ & $8.89 * *$ & $661.25^{* *}$ & 365.20 \\
\hline$\hat{\sigma}_{P}^{2}$ & 52.93 & 0.22 & 2.21 & 72.12 & 50.30 & 3.56 & 32.80 & 2.55 \\
\hline$\hat{\sigma}_{E}^{2}$ & 15.52 & 0.17 & 0.44 & 14.10 & 12.04 & 0.11 & 7.56 & 8.00 \\
\hline$\phi_{G}$ & 51.00 & 0.17 & 2.08 & 69.55 & 48.88 & 3.46 & 29.62 & 0.99 \\
\hline Mean & 28.11 & 1.28 & 1.97 & 24.96 & 24.97 & 2.27 & 9.53 & 13.23 \\
\hline $\mathrm{CV}_{e}(\%)$ & 14.01 & 32.21 & 33.67 & 15.04 & 13.90 & 14.61 & 28.85 & 21.38 \\
\hline $\mathrm{CV}_{g}(\%)$ & 25.40 & 31.85 & 73.21 & 33.40 & 28.00 & 81.94 & 57.11 & 7.52 \\
\hline $\mathrm{I}_{v}$ & 1.81 & 1.00 & 2.17 & 2.22 & 2.01 & 5.61 & 1.98 & 0.35 \\
\hline $\mathrm{H}^{2}(\%)$ & 96.35 & 77.27 & 94.12 & 96.44 & 97.18 & 97.19 & 90.3 & 38.82 \\
\hline
\end{tabular}

GMS: genotype mean square; GSMS: mean square due to genotype x season interaction; $\mathrm{CV}_{\mathrm{e}}$ : coefficient of experimental variation; $\mathrm{CV}_{\mathrm{g}}$ : coefficient of genetic variation; $\mathrm{H}^{2}$ : genotypic determination coefficient. TNFr: total number of fruits; $\mathrm{NCFr}$ : number of carpelloid fruits; $\mathrm{NPFr}$ : number of pentandric fruits; NMFr: number of marketable fruits; TNHF: total number of hermaphrodite flowers; NDHF: number of deformed hermaphrodite flowers; NSHF: number of sterile hermaphrodite flowers; NNHF: number of normal hermaphrodite flowers;** significant at $1 \%$ probability.

environmental factors, in view of the negative $\mathrm{H}^{2}$ values for NNHF.

The ratio between the genotypic and experimental coefficient of variation is called experimental variation index $\left(\mathrm{I}_{\mathrm{v}}\right)$, a parameter which allows the detection of genetic variability in a population and has the advantage of indicating the true magnitude of a trait. The $\mathrm{I}_{\mathrm{v}}$ values (Table 2) ranged from 0.35 (NNHF) to 5.61 (NDHF), while the analysis at different times (Table 3 ) showed values of 1.87 - 6.08 in the winter, $1.44-4.53$ in spring, $0.66-5.61$ in summer and from 0 to 1.82 in the fall. According to Vencovsky (1987), in tests of maize progenies, the situation is highly favorable for selection when the value of this index is $\geq 1$. Accordingly, chances are high for a favorable response to selection for the traits evaluated in this study, except for NNHF. Regarding the seasons, the conditions in winter and spring were more favorable for selection due to the higher $I_{v}$ values for all variables, confirmed by the analyses of the genotypic variation and genotypic determination coefficients.

The mean values for all traits (Table 3) showed a higher expression of normal and deformed flowers in summer, while most total and sterile flowers are produced in spring. Aside from the pentandric fruits, with highest incidence in spring, the expression of all fruiting traits was highest in the summer.

The highest mean values for NDHF were observed in the progenies $\mathrm{BC}_{2}$ and $52 \mathrm{BC}_{1} \mathrm{~S}_{1}$ (Table 4). Although the period of highest incidence of flower malformation was in the summer, the means of the two above treatments were highest in spring and winter, respectively, indicating a greater influence of low and mild temperatures on families that are more sensitive to the expression of this trait. Among the segregating progenies, the lowest incidence of this variable was observed in progenies $115 \mathrm{BC}_{1} \mathrm{~S}_{1}$, followed by 'SS72/12' x $\mathrm{BC}_{1}$ and $16 \mathrm{BC}_{1} \mathrm{~S}_{1}$, suggesting 
Seasonal and genetic influences on sex expression in a backcrossed...

Table 3. Summary of the analyses of variance of morphoagronomical traits in segregating generations and in papaya elite genotypes, evaluated in four different seasons of the year

\begin{tabular}{|c|c|c|c|c|c|c|c|c|}
\hline \multirow{3}{*}{ Estimates } & \multicolumn{8}{|c|}{ Traits } \\
\hline & TNFr & NCFr & NPFr & NMFr & TNHF & NDHF & NSHF & NNHF \\
\hline & \multicolumn{7}{|c|}{ Winter $(n=20)$} & \\
\hline GMS & $11,695.90 * *$ & $22.46 * *$ & $110.68 *$ & $13,667.23 * *$ & $2,710.67 * *$ & $344.19^{* *}$ & $986.64 * *$ & $623.09 * *$ \\
\hline$\hat{\sigma}_{P}^{2}$ & 292.37 & 0.56 & 2.77 & 341.68 & 67.77 & 8.60 & 24.67 & 15.58 \\
\hline$\hat{\sigma}_{E}^{2}$ & 15.82 & 0.05 & 0.69 & 9.44 & 4.95 & 0.23 & 3.58 & 2.24 \\
\hline$\phi_{G}$ & 284.46 & 0.54 & 2.42 & 336.96 & 65.31 & 8.49 & 22.88 & 14.45 \\
\hline Mean & 30.54 & 0.85 & 1.13 & 28.87 & 16.35 & 2.28 & 4.10 & 10.06 \\
\hline $\mathrm{CV}_{e}(\%)$ & 13.02 & 25.50 & 73.51 & 10.64 & 13.61 & 21.03 & 46.15 & 14.88 \\
\hline $\mathrm{CV}_{g}(\%)$ & 55.22 & 86.45 & 137.67 & 63.58 & 49.43 & 127.80 & 116.67 & 37.79 \\
\hline $\mathrm{I}_{v}$ & 4.24 & 3.39 & 1.87 & 5.97 & 3.63 & 6.08 & 2.53 & 2.54 \\
\hline $\mathrm{H}^{2}(\%)$ & 97.29 & 96.43 & 87.36 & 98.62 & 96.37 & 98.72 & 92.74 & 92.75 \\
\hline \multicolumn{9}{|c|}{ Spring $(n=20)$} \\
\hline GMS & $3,008.86^{* *}$ & $33.81 * *$ & $664.4^{* *}$ & $4,367.34 * *$ & $7,453.20 * *$ & $361.19^{* *}$ & $5,658.70^{*}$ & $1,200.12 *$ \\
\hline$\hat{\sigma}_{P}^{2}$ & 75.22 & 0.84 & 16.61 & 109.18 & 186.18 & 6.03 & 141.47 & 30.01 \\
\hline$\hat{\sigma}_{E}^{2}$ & 10.87 & 0.05 & 1.55 & 10.13 & 13.58 & 0.43 & 35.43 & 11.68 \\
\hline$\phi_{G}$ & 69.80 & 0.82 & 15.83 & 104.12 & 179.54 & 8.81 & 123.75 & 24.16 \\
\hline Mean & 20.72 & 1.30 & 2.74 & 16.67 & 33.45 & 2.14 & 16.22 & 15.13 \\
\hline $\mathrm{CV}_{e}(\%)$ & 15.91 & 17.20 & 45.44 & 19.10 & 11.02 & 30.64 & 36.70 & 22.59 \\
\hline $\mathrm{CV}_{g}(\%)$ & 40.32 & 69.66 & 145.21 & 61.21 & 40.06 & 138.70 & 68.58 & 32.49 \\
\hline $\mathrm{I}_{v}$ & 2.53 & 4.05 & 3.20 & 3.22 & 3.64 & 4.53 & 1.87 & 1.44 \\
\hline $\mathrm{H}^{2}(\%)$ & 92.79 & 97.62 & 95.3 & 95.37 & 96.35 & 97.00 & 87.47 & 80.53 \\
\hline \multicolumn{9}{|c|}{ Summer $(n=15)$} \\
\hline GMS & $2,395.50^{* *}$ & 3.07 & $56.27 * *$ & $3,056.53 * *$ & $1,045.54^{* *}$ & $153.57^{* *}$ & $543.67 *$ & 84.83 \\
\hline$\hat{\sigma}_{P}^{2}$ & 79.85 & 0.10 & 1.87 & 101.88 & 34.85 & 5.12 & 18.12 & 2.83 \\
\hline$\hat{\sigma}_{E}^{2}$ & 7.01 & 0.16 & 0.18 & 8.26 & 2.24 & 0.16 & 5.23 & 3.03 \\
\hline$\phi_{G}$ & 76.35 & 0.02 & 1.78 & 97.76 & 33.73 & 5.04 & 15.51 & 1.31 \\
\hline Mean & 36.95 & 2.12 & 2.54 & 32.30 & 25.95 & 2.92 & 7.13 & 15.91 \\
\hline $\mathrm{CV}_{e}(\%)$ & 7.16 & 18.87 & 16.70 & 8.90 & 5.77 & 13.70 & 32.07 & 10.94 \\
\hline $\mathrm{CV}_{g}(\%)$ & 23.65 & 6.67 & 52.53 & 30.61 & 22.38 & 76.88 & 55.23 & 7.19 \\
\hline $\mathrm{I}_{v}$ & 3.30 & 0.35 & 3.15 & 3.44 & 3.88 & 5.61 & 1.72 & 0.66 \\
\hline $\mathrm{H}^{2}(\%)$ & 95.00 & 20.00 & 95.19 & 95.96 & 96.79 & 98.44 & 85.6 & 46.29 \\
\hline \multicolumn{9}{|c|}{ Fall $(n=5)$} \\
\hline GMS & 359.23 & 6.34 & $17.46^{*}$ & 408.49 & $816.62 *$ & $27.95^{*}$ & $617.85^{*}$ & 54.59 \\
\hline$\hat{\sigma}_{P}^{2}$ & 35.92 & 0.64 & 1.75 & 40.85 & 81.66 & 2.79 & 61.79 & 5.46 \\
\hline$\hat{\sigma}_{E}^{2}$ & 36.76 & 1.26 & 0.59 & 49.11 & 33.90 & 0.73 & 16.36 & 18.57 \\
\hline$\phi_{G}$ & 17.54 & 0.01 & 1.45 & 16.29 & 64.71 & 2.43 & 53.61 & 0 \\
\hline Mean & 26.06 & 1.00 & 1.06 & 24.00 & 26.24 & 1.04 & 12.24 & 12.95 \\
\hline $\mathrm{CV}_{e}(\%)$ & 23.26 & 112.25 & 72.46 & 29.20 & 22.19 & 82.15 & 33.04 & 33.28 \\
\hline $\mathrm{CV}_{g}(\%)$ & 16.07 & 10.00 & 113.60 & 16.82 & 30.66 & 149.89 & 59.82 & 0 \\
\hline $\mathrm{I}_{v}$ & 0.70 & 0.09 & 1.57 & 0.58 & 1.38 & 1.82 & 1.81 & 0 \\
\hline $\mathrm{H}^{2}(\%)$ & 48.83 & 0.78 & 82.85 & 39.88 & 79.24 & 87.10 & 86.76 & 0 \\
\hline
\end{tabular}

**, * significant at $1 \%$ and $5 \%$ probability, respectively.

these as the most suitable for selection of genotypes with lower incidence of malformation.

In studies conducted in Hawaii it was reported that the presence of high moisture, low temperature and excess soil nitrogen favored the development of flowers producing carpelloid and pentandric fruit (Awada and Ikeda 1957). However, Dantas and Morales (1997) add that considerable changes in temperature in the warmer months, besides the previously mentioned factors, may induce the expression of this type of malformation.

In the two seasons with highest NSHF (spring and autumn) the $\mathrm{CV}_{\mathrm{g}}$ values were also highest, indicating the possibility of success in the selection of genotypes less responsive to this type of anomaly. However, a higher 
HCC Ramos et al.

Table 4. Mean values and least significant difference (LSD), for flower traits in segregating generations and in papaya elite genotypes, evaluated in four different seasons

\begin{tabular}{|c|c|c|c|c|c|c|c|c|}
\hline \multirow{2}{*}{ Treatments } & Winter & Spring & Summer & Fall & Winter & Spring & Summer & Fall \\
\hline & \multicolumn{4}{|c|}{ TNHF } & \multicolumn{4}{|c|}{ NDHF } \\
\hline $16 \mathrm{BC}_{1} \mathrm{~S}_{1}$ & 24.58 & 44.31 & 22.33 & 41.10 & 0.35 & 0.44 & 0.73 & 0.00 \\
\hline $52 \mathrm{BC}_{1} \mathrm{~S}_{1}$ & 16.61 & 36.39 & 27.70 & 23.60 & 3.67 & 2.30 & 2.93 & 2.10 \\
\hline $115 \mathrm{BC}_{1} \mathrm{~S}_{1}$ & 33.41 & 68.27 & 48.00 & 47.80 & 0.35 & 0.27 & 0.00 & 0.00 \\
\hline $72 / 12 \times \mathrm{BC}_{1}$ & 9.84 & 26.83 & 19.57 & 19.09 & 0.00 & 0.02 & 1.60 & 0.27 \\
\hline $\mathrm{BC}_{2}$ & 15.39 & 33.37 & 31.27 & 29.45 & 5.47 & 6.26 & 6.03 & 4.18 \\
\hline Golden & 8.30 & 17.90 & 20.40 & 15.90 & 0.07 & 0.03 & 1.00 & 0.00 \\
\hline SS 783 & 7.83 & 13.76 & 22.15 & 19.60 & 0.00 & 0.00 & 1.45 & 0.00 \\
\hline \multirow[t]{2}{*}{$\operatorname{LSD}(5 \%)$} & 5.45 & 9.03 & 3.67 & 14.26 & 1.17 & 1.61 & 0.98 & 2.09 \\
\hline & & & & NSHF & & & & INHF \\
\hline $16 \mathrm{BC}_{1} \mathrm{~S}_{1}$ & 9.61 & 26.79 & 7.80 & 24.30 & 14.63 & 17.18 & 13.80 & 16.80 \\
\hline $52 \mathrm{BC}_{1} \mathrm{~S}_{1}$ & 2.42 & 11.77 & 10.30 & 10.70 & 10.51 & 22.32 & 14.47 & 10.80 \\
\hline $115 \mathrm{BC}_{1} \mathrm{~S}_{1}$ & 14.94 & 54.27 & 23.60 & 30.40 & 18.12 & 13.73 & 24.40 & 17.40 \\
\hline $72 / 12 \times \mathrm{BC}_{1}$ & 1.48 & 12.02 & 1.90 & 6.55 & 8.63 & 14.72 & 16.07 & 12.27 \\
\hline $\mathrm{BC}_{2}$ & 2.55 & 13.92 & 8.33 & 13.73 & 7.53 & 13.08 & 17.13 & 11.55 \\
\hline Golden & 0.83 & 9.40 & 2.70 & 2.60 & 7.40 & 8.47 & 16.70 & 13.30 \\
\hline SS 783 & 0.93 & 5.65 & 5.10 & 9.30 & 6.90 & 8.10 & 15.60 & 10.30 \\
\hline $\operatorname{LSD}(5 \%)$ & 4.63 & 14.58 & 5.6 & 9.91 & 3.67 & 8.37 & 4.26 & 10.56 \\
\hline
\end{tabular}

TNHF: total number of hermaphrodite flowers; NDHF: number of deformed hermaphrodite flowers; NSHF: number of sterile hermaphrodite flowers; NNHF: number of normal hermaphrodite flowers; LSD: Least significant difference.

Table 5. Mean values and least significant difference (LSD) for the traits related to fruiting in segregating generations and in papaya elite genotypes, evaluated in four different seasons

\begin{tabular}{|c|c|c|c|c|c|c|c|c|}
\hline \multirow{2}{*}{ Treatments } & Winter & Spring & Summer & Fall & Winter & Spring & Summer & Fall \\
\hline & \multicolumn{4}{|c|}{ TNHF } & \multicolumn{4}{|c|}{ NDHF } \\
\hline $16 \mathrm{BC}_{1} \mathrm{~S}_{1}$ & 21.15 & 11.62 & 29.03 & 20.70 & 0.58 & 1.17 & 2.37 & 0.90 \\
\hline $52 \mathrm{BC}_{1} \mathrm{~S}_{1}$ & 35.41 & 32.26 & 36.93 & 28.20 & 1.27 & 1.80 & 1.63 & 1.00 \\
\hline $115 \mathrm{BC}_{1} \mathrm{~S}_{1}$ & 14.71 & 11.09 & 31.20 & 11.80 & 0.05 & 0.27 & 1.00 & 0.00 \\
\hline $72 / 12 \times \mathrm{BC}_{1}$ & 51.49 & 22.54 & 49.20 & 32.64 & 0.13 & 0.33 & 2.13 & 1.64 \\
\hline $\mathrm{BC}_{2}$ & 17.02 & 16.51 & 28.90 & 22.27 & 1.62 & 2.27 & 2.43 & 2.18 \\
\hline Golden & 46.40 & 21.93 & 49.50 & 25.60 & 0.17 & 0.13 & 2.00 & 0.00 \\
\hline SS 783 & 51.77 & 28.48 & 43.55 & 33.80 & 0.33 & 0.86 & 2.15 & 0.60 \\
\hline \multirow[t]{2}{*}{$\operatorname{LSD}(5 \%)$} & 9.74 & 8.08 & 6.49 & 14.85 & 0.53 & 0.98 & 0.98 & 2.17 \\
\hline & & & & NSHF & & & & NNHF \\
\hline $16 \mathrm{BC}_{1} \mathrm{~S}_{1}$ & 0.18 & 0.59 & 2.70 & 1.00 & 20.39 & 9.56 & 23.97 & 18.80 \\
\hline $52 \mathrm{BC}_{1} \mathrm{~S}_{1}$ & 1.29 & 2.62 & 3.00 & 3.60 & 32.85 & 27.83 & 32.30 & 23.60 \\
\hline $115 \mathrm{BC}_{1} \mathrm{~S}_{1}$ & 0.00 & 0.00 & 0.00 & 0.00 & 15.10 & 10.82 & 30.20 & 11.80 \\
\hline $72 / 12 \times \mathrm{BC}_{1}$ & 0.00 & 0.20 & 1.57 & 0.36 & 51.36 & 22.02 & 45.50 & 30.64 \\
\hline $\mathrm{BC}_{2}$ & 3.11 & 8.35 & 4.07 & 1.91 & 12.79 & 5.89 & 22.40 & 18.18 \\
\hline Golden & 0.00 & 0.00 & 1.60 & 0.00 & 46.23 & 21.80 & 45.90 & 25.60 \\
\hline SS 783 & 0.00 & 0.00 & 0.05 & 0.00 & 51.43 & 27.62 & 41.35 & 33.20 \\
\hline $\operatorname{LSD}(5 \%)$ & 2.03 & 3.05 & 1.04 & 1.88 & 7.53 & 7.8 & 7.04 & 17.17 \\
\hline
\end{tabular}

TNFr: total number of fruits; NCFr: number of carpelloid fruits; NPFr: number of pentandric fruits; NMFr: number of marketable fruits; LSD: Least significant difference.

expression of this trait in the summer has been observed in other studies with papaya under the environmental conditions of Hawaii (Awada 1958, Nakasone et al. 1972) and in Brazil (Silva et al. 2007a, Damasceno Junior et al.
2008), indicating that factors other than temperature may be have a considerable influence on this trait. In the treatments, significant sensitivity to sex reversal was observed in $115 \mathrm{BC}_{1} \mathrm{~S}_{1}$, followed by $16 \mathrm{BC}_{1} \mathrm{~S}_{1}$. On the other 
hand, the treatments 'SS72/12' $x \mathrm{BC}_{1}$ and $52 \mathrm{BC}_{1} \mathrm{~S}_{1}$ were less affected by factors that induce sex reversal, indicating these genotypes as promising for selection.

The mean number of normal hermaphrodite flowers (NNHF) was statistically only slightly different between treatments, with no variation in autumn, indicating a uniform trait expression among the treatments at this time of the year. This result was corroborated by low $\mathrm{CV}_{\mathrm{g}}$ values found in the different seasons. Means were highest for treatment $115 \mathrm{BC}_{1} \mathrm{~S}_{1}$ in almost all evaluation periods. This same genotype also proved superior in the total number of flowers (TNHF) in the four seasons evaluated, and seems to be promising for the advancement of generations. On the other hand, the lowest means for NNHF and TNHF were observed for the genotype SS783 and 'Golden', respectively, indicating a moderate to high superiority of the segregating over the elite genotypes.

In the expression of TNHF and NNHF an association was observed between the two traits, since in the treatments with highest TNHF the NNHF was also highest. This result was corroborated by the study of genetic correlations between morphological traits of papaya, where TNHF and NNHF were positively and strongly (0.95) correlated, indicating that the total number of hermaphroditic flowers can be an indicator of yield (Silva et al. 2007c).

This analysis of flowering clearly showed the complexity in the expression of floral traits, as pointed out in studies with model plants, where the flowering process is regulated by a complex signaling pathway, modulated by environmental conditions (Samachar and Coupland 2000). One may suggest that these traits are very sensitive to external stimuli. These environmental signals may induce complex activation and interaction of a group of genes, making the analysis of inheritance and expression of these traits rather difficult. Given this complexity in papaya sex expression, it has been suggested that the traits related to flowering as well as fruiting should be considered quantitative (Damasceno Júnior et al. 2008).

In relation to fruiting (Table 5), the analysis of the least significant difference (LSD) for TNFr revealed no difference between means of 'SS72/12' x BC, 'Golden' and SS783, in the four seasons, indicating that these genotypes respond similarly to different environmental stimuli. This similar behavior between 'SS72/12' x BC 1 and the elite genotypes was not at all unexpected, since this genotype results from a cross between a plant of the $\mathrm{BC}_{1}$ population, with an average of $75 \%$ of the genome Cariflora, and a plant of variety 'SS72/12', which is genetically very close to SS783. Thus, it is expected that the plants of 'SS72/ 12 ' $\mathrm{X} \mathrm{BC}_{1}$ have on average $50 \%, 37.5 \%$ and $12.5 \%$ of the genome 'SS72/12', Cariflora and SS783, respectively, in which $62.5 \%$ is genome of the 'Solo' group.

An increased expression of carpelloid fruit (NCFr) in the summer was found for most treatments, except $52 \mathrm{BC}_{1} \mathrm{~S}_{1}$, peaking in spring. In general, the occurrence of pentandric fruits (NPFr) was $15 \%$ higher than of carpelloid fruits. On the other hand, the expression of both traits is rather marked in the summer months. The means for NPFr of the genotypes $52 \mathrm{BC}_{1} \mathrm{~S}_{1}$ and $\mathrm{BC}_{2}$ were the highest in the four seasons, peaking in autumn and spring, respectively. The expression of NPFr was zero in the four seasons for 115 $\mathrm{BC}_{1} \mathrm{~S}_{1}$, demonstrating a superior performance to elite genotypes 'Golden' and SS783.

Silva et al. (2007a) argue that the malformation of flowers and consequently, of fruit in segregating generations from this backcrossing program are probably partly due to genetic inheritance of the genotype Cariflora since in dioecious plants this malformation would never be expressed. In contrast, the donor parent is an elite genotype planted frequently for commercial purposes, with greater uniformity and low level of malformations, which was confirmed by the data presented here.

Similar results were observed for the expression of NMFr and TNFr in summer, however, for these latter trait values were slightly higher. One explanation for this reduction of NMFr compared to TNFr in summer is the greater expression of fruit malformation (carpelloid and pentandric) in this season, contributing to a yield decrease. The highest means of NMFr in segregating progenies were observed for $52 \mathrm{BC}_{1} \mathrm{~S}_{1}$ and ' $\mathrm{SS} 72 / 12$ ' $\mathrm{x} \mathrm{BC}$, but none of these means was statistically different from the cultivars SS783 and 'Golden'. These results are quite satisfactory and in the future, different genotypes can be planted aimed at increasing diversity in the field aside from reducing yield fluctuation, decreasing variations in fruit supply and price.

In a comparison of the flowering with the fruiting data, a low representativeness of the first in relation to the second was observed and vice versa, making the establishment of predictions for the papaya improvement program difficult. Thus, the evaluation of fruiting instead of flowering may be more efficient, making the evaluation process faster, more practical and straightforward, as well as more informative. For sex reversal, where there is no fruit development, the assessment could be based on the measurement of the "neck", which is also a practical and 
quick method, contributing to greater success in the selection.

The instability observed in the genotypes in the four seasons of evaluation indicated that a strong influence of climate alterations and other abiotic stresses that induce the expression of anomalies, aside from the existence of a distinct behavior of the genotypes in response to environmental influences. This implies the possibility of genetic progress through selection procedures. Based on statistical analysis it can be inferred that the expression of all traits in winter and spring is more determined by genetic than by environmental factors, aside from the greater genetic variability, indicating these seasons for selection. On the other hand, in the summer the influence of environmental factors on the expression of some traits is greater, mainly in the production of carpelloid fruits and normal hermaphrodite flowers. In the fall this environmental influence is even higher, affecting the trait expression considerably. Thus, it is possible to suggest that the selection of genotypes with a lower incidence of anomalies (malformations and sex reversal) and higher rates of normal flowers and marketable fruit should be carried out in the winter and spring months. Of the progenies, $52 \mathrm{BC}_{1} \mathrm{~S}_{1}$ with uniform performance in all traits is indicated for the selection of superior genotypes.
The evaluation of genotypes in the four seasons helped understand the floral behavior under different environmental stimuli, so the selection process can be conducted more efficiently. Thus, it appears that in the first evaluation periods (winter and spring) contribution of genetic components to the total variance was greater, as indicated by the values of $\mathrm{H}^{2}, \mathrm{CV}_{\mathrm{g}}$ and $\mathrm{I}_{\mathrm{v}}$. Accordingly, since the data were arranged in chronological order, it became evident that the success with selection can be maximized in the early stages of plant development rather than in later periods, an antagonistic behavior to typically perennial species. This may explain the divergent results reported in studies on sex expression in papaya, indicating that the physiological plant age may also be a factor involved in the complex pathway of reproductive trait expression in papaya. Thus, the earlier the assessments the greater is the possibility of selecting genetically superior segregating plants due to the reduced influence of environmental factors on the phenotype expression.

\section{ACKNOWLEDGEMENTS}

We thank the Brazilian Federal Agency for Support and Evaluation of Graduate Education (CAPES) for a graduate scholarship and the Brazilian Innovation Agency (FINEP) and the Company Caliman Agrícola S/A (CALIMAN) for financial and logistical support.

\title{
Influências genéticas e sazonais na expressão sexual em população segregante de mamoeiro derivada de retrocruzamento
}

\begin{abstract}
RESUMO - Este estudo objetivou avaliar o comportamento genético e sazonal da expressão do sexo em gerações segregantes de mamoeiro oriundas de retrocruzamento e em genótipos elite. Avaliou-se 200 plantas hermafroditas nas quatro estações, nos anos 2005/2006. Das oito características avaliadas, quatro foram ligadas à floração e quatro referentes à frutificação, a citar, proporção de flores normais, deformadas, estéreis e totais, além da proporção de frutos totais, carpelóides, pentândricos e comerciais. Os resultados possibilitaram verificar a existência de diferença significativa para a interação genótipo versus estação do ano. Com base no coeficiente de determinação genotípica, bem como no índice de variação conclui-se que o inverno e a primavera são as épocas mais propícias para a seleção de genótipos superiores. Assim, maior sucesso pode ser alcançado com a seleção em estágios iniciais do desenvolvimento da planta, indicando que a idade fisiológica pode ser mais um fator envolvido na expressão das características avaliadas.
\end{abstract}

Palavras-chave: Carica papaya L., deformações florais, reversão sexual, sazonalidade. 


\section{REFERENCES}

Arkle Junior TD and Nakasone HY (1984) Floral differentiation in the hermaphroditic papaya. HortScience 19: 832-834.

Awada M and Ikeda WS (1957) Effects of water and nitrogen application on composition, growth, sugars in fruits, and sex expression of the papaya plants (Carica papaya L.). Hawaii Agricultural Experiment Station, Technical Bulletin 38: $1-16$.

Awada M (1958) Relationships of minimum temperature and growth rate with sex expression of papaya plants (Carica papaya L.). Hawaii Agricultural Experiment Station, Technical Bulletin 38: 1-16.

Damasceno Júnior PC, Pereira TNS, Silva FF, Viana AP and Pereira MG (2008) Comportamento floral de híbridos de mamoeiro (Carica papaya L.) avaliados no verão e primavera. Ceres 55 : 310-316.

Dantas JLL and Morales CFG (1997) Estratégias para o melhoramento genético do mamoeiro. Revista Brasileira de Fruticultura 19: 65-78.

Fehr WR (1987) Principles of cultivar development: theory and technique. vol. 1, Iowa State University, Iowa, 525p.

INCAPER (2006) Available at <http://cecam.incaper.es.gov.br/ index.php> Assessed on Nov. 20.

Khan S, Tyagi AP, Jokhan A (2002) Sex ratio in Hawaiian papaya (Carica papaya L.) variety 'Solo'. South Pacific Journal of Natural Science 20: 22-24.

Liu Z, Moore PH, Ma H, Ackerman CM, Ragiba M, Yu Q, Peari HM, Kim MS, Chariton JW, Stiles JI, Zee FT, Andrew AH and Ming R (2004) A primitive $Y$ chromosome in papaya marks incipient sex chromosome evolution. Nature 427: 348-352.

Ming R, Yu Q, Moore PH (2007) Sex determination in papaya. Seminars in Cell \& Development Biology 18: 401-408.

Nakasone HY, Crozier JA and Ikehara DK (1972) Evaluation of 'Waimanalo', a new papaya strain. Technical Bulletin 79: 112.
Rolim SG, Couto HTZ and Jesus RM (1999) Mortalidade e recrutamento de árvores na Floresta Atlântica de Linhares (ES). Scientia Forestalis 55: 49-69.

Samach A and Coupland G (2000) Time measurement and the control of flowering in plants. Bioessays 22: 38-47.

SAS Institute (1992) Statistical analyses system. Version 6.12. SAS, Cary.

Silva FF, Pereira MG, Damasceno Junior PC, Pereira TNS, Viana AP, Daher RF, Ramos HCC and Ferreguetti GA (2007a) Evaluation of the sexual expression in a segregating $\mathrm{BC}_{1}$ papaya population. Crop Breeding and Applied Biotechnology 7: 16-23.

Silva FF, Pereira MG, Campos WF, Damasceno Júnior PC, Pereira TNS, Souza Filho GA, Ramos HCC, Viana AP and Ferreguetti GA (2007b) DNA marker-assisted sex conversion in elite papaya genotype (Carica papaya L.). Crop Breeding and Applied Biotechnology 7: 52-58.

Silva FF, Pereira MG, Ramos HCC, Damasceno Junior PC, Pereira TNS and Ide CD (2007c) Genotypic correlations of morphoagronomic traits in papaya and implications for genetic breeding. Crop Breeding and Applied Biotechnology 7: 345-352.

Steel GDD and Torrie JH (1980) Principles and procedures of statistics. McGraw-Hill, New York, 633p.

Storey WB (1953) Genetics of the papaya. Journal of Heredity 44: $70-78$.

Venkovsky R (1987) Herança quantitativa. In Paterniani E and Viegas GP (eds.) Melhoramento e produção do milho. Fundação Cargill, Campinas, p. 135-214.

Yu Q, Hou S, Feltus FA, Jones MR, Murray JE, Veatch O, Lemke C, Saw JH, Moore RC, Thimmapuram J, Liu L, Moore PH, Alam M, Jiang J, Paterson AH and Ming R (2008) Low X/Y divergence in four pairs of papaya sex-linked genes. The Plant Journal 53: $124-132$. 